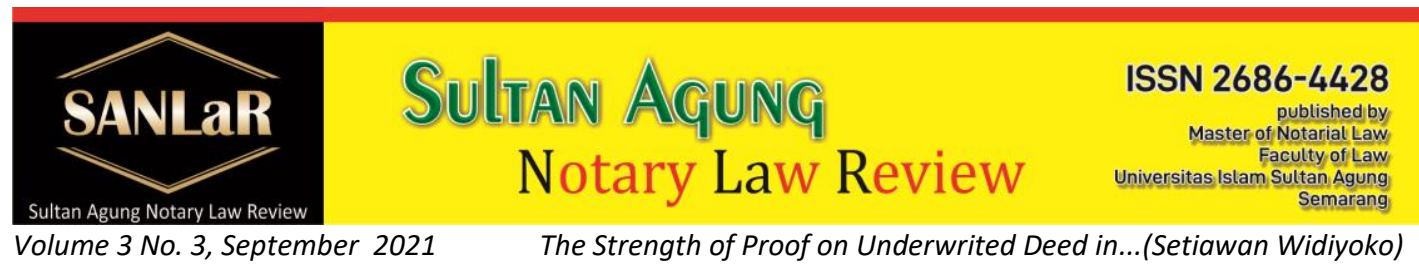

\title{
The Strength of Proof on Underwrited Deed in Waarmeking by a Notary
}

\author{
Setiawan Widiyoko*) \\ *) Faculty of Law, Universitas Islam Sultan Agung (UNISSULA) Semarang, E-mail: \\ setiawan.wd@gmail.com
}

\begin{abstract}
The power of proof of an underhand deed as evidence in court in connection with the authority of a Notary in carrying out Legalization and Waarmeking based on articles 1874, 1874 (a) and 1880 BW of the letter evidence must have legalization or waarmeking from the authorized official. In Decision Number 13 PDT/2020/PT.MTR there is a difference in Judex Factie in the trial between the Praya District Court and the Mataram High Court. This study analyzes how aspects of the strength of proof of underhand deeds that have been legalized or waarmeking by a Notary and legal considerations applied by judges in examining and deciding the case. This study uses a normative juridical legal research method, namely legal research conducted by examining materials derived from various laws and regulations and other materials from various literatures that have correlation and relevance to the problems to be studied, as well as legal theories and opinions of scholars. The underhanded deed which is waarmeking is perfect evidence, the contents of the underhand deed that have been registered at a Notary with the signing of the parties are valid, the proof value of the underhand deed must meet formal and material requirements, then the proof value is the same as the authentic deed, namely the proof value. perfectly attached and binding, while the power of proof of a deed under the hand that has been waarmeking in evidence at trial has imperfect proving power when each party denies the contents of the agreement. Notaries in carrying out their duties must be in accordance with applicable laws and regulations so that there are no disputes over agreements that have been waarmeking. so that it has perfect proof of certainty in the eyes of the law.
\end{abstract}

Keywords: Deed; Under Hand; Waarmeking; Proof.

\section{Introduction}

Article 1 paragraph (3) of the 1945 Constitution of the Republic of Indonesia, the State of Indonesia is a state of law. The state based on law is characterized by several principles, including that all actions or actions of a person, both 
individuals and groups, the people and the government, must be based on legal provisions and statutory regulations that existed before the act or action was carried out or based on applicable regulations. The basic idea of the rule of law, both in the concept of "rechtsstaat" and "the rule of law," is the main goal of protecting basic human rights. In the concept of rechtsstaat the protection of basic rights is realized through the principle of legality. With this principle, the law must be positive, meaning that the law must be formed consciously and set forth in an official and definite form such as the enactment of Act No. 02 of 2014 concerning Amendments to Act No. 30 of 2004 concerning the Position of a Notary. ${ }^{1}$

Staatsblad 1860 Number 3 concerning the regulation of Notary positions in Indonesia (Reglemen op het Notaris-ambt in Indonesia) in article 1 states that Notaries are public officials, especially authorized to make authentic deeds regarding all acts, approvals and stipulations, which is to be ordered by a general law or desired by interested persons, which will be proven by authentic writing, guaranteeing the day and date, distorting deeds and issuing grosse-grosse, copies and quotations thereof, all that is to the extent that the making of the said deeds by general law is also assigned or handed over to officials or other people. ${ }^{2}$ Notary as one of the law enforcers because the Notary makes written evidence that has the power of proof. Legal experts are of the opinion that a Notary's deed can be accepted in court as absolute evidence of its contents, but even so, a denial can be made with evidence to the contrary by witnesses, who can prove that what the Notary has explained in the deed is true. ${ }^{3} T$ The government wants a Notary as a public official who is appointed and dismissed by the government and given the authority and obligation to be able to provide services $^{4}$ to the community in helping to make agreements, make deeds and their ratification which is also the authority of the Notary. Despite being referred to as acting General. ${ }^{5}$

Article 1865 of the Civil Code which states: "Everyone who argues that he has a right, or to confirm his own right or to refute a right of another, refers to an event, is obliged to prove the existence of that right or event". Article 1866 The

\footnotetext{
${ }^{1}$ Rahmadhani, Febri "Kekuatan Pembuktian Akta di Bawah Tangan Waarmerking Dalam Perspektif Peraturan Perundang-undangan di Indonesia" Jurnal Recital Review, Vol. 2, No. 2, 2020, hal. 29, url:https://online-journal.unja.ac.id/RR/article/view/9135 accessed on 12 January 2020 at 03.00 WIB

${ }^{2}$ Salim, HS, Peraturan Jabatan Notaris, (Jakarta Timur: Sinar Grafika, 2018), p. 15

${ }^{3}$ Ngadino. Tugas dan Tanggungjawab Jabatan Notaris di Indonesia, ( Semarang, Universitas PGRI Pres, 2019), p. 3 quoted from Liliana Tedjosaputro, (1991) Malpraktek Notaris dan Hukum Pidana, p.4

${ }^{4}$ Deen, Thaufiq., Ong Argo Victoria \& Sumain. (2018). Public Notary Services In Malaysia. JURNAL AKTA: Vol. 5, No. 4, 1017-1026. Retrieved from http://jurnal.unissula.ac.id/index.php/akta/article/view/4135

${ }^{5}$ Ibid, p.4
} 
Civil Code stipulates that the evidence consists of written/letter evidence, evidence with witnesses, conjectures, confessions, and oaths. In the Civil Code regarding written evidence, the arrangement can be seen in Article 1867-1894, where Article 1867 of the Civil Code states that written evidence is carried out in authentic writings or in writing under the hand. Looking at the provisions in book IV of the Civil Code in Articles 1874, 1874a, In 1880 it was stated that the documents in question needed to be legalized by a notary. In relation to the authority of a Notary as a General Officer, an underhand letter can be strengthened through legalization and waarmeking (registration). The difference between Register (Waarmeking) and Legalization is: "Waarmeking" only has a certain date and there is no certainty of a signature, while the legalization of the signature is carried out in front of the legalizing person, while for waarmeking, at the time of waarmeking, the letter is already signed by the person concerned. So the one who gave the waarmeking didn't know and therefore didn't certify his signature." ${ }^{6}$ This private registration of letters or waarmeking has not been specifically and editorially regulated, but regarding legalization, it can be found in Act No. 2 of 2014 concerning Amendments to Act No. 30 of 2004 concerning Notary Positions, in Article 15 paragraph (2) letter a states that the Notary in his position has the authority to ratify the signature and determine the certainty of the date of the letter under the hand by registering it in a special book. However, the application of private letters registered by a notary has many problems, many have misunderstood, an underhand letter registered by a notary does not have a clear legal basis, it is only regulated in the Law on Notary Positions. According to the contents of the article, a notary is authorized to:

PT. Lombok Mulia Jaya, represented by its Director named Lee Jong Kwak, (Comparison/ Appellate II/ Originally Plaintiff) Against Rui Jun, a Chinese citizen. The trial process Judex factie at the Praya District Court stated that "Stating the Law that the Joint Venture Cooperation agreement Number: 352/WAARMEKING/2017 dated 30 May 2017 Notary Adrianto Anwar, SH, M.Kn and the contents of the cooperation agreement dated 17 November 2018 remain binding until Defendant of Countermeasures/Plaintiff of Convention has fulfilled his obligation". This is different from the view in the Judex Factie trial at the Mataram High Court which stated that: "Declare the joint venture agreement made under the hand that has been in Waarmeking at the Notary Office of Adrianto Anwar, SH, M.Kn Notary in Jakarta, under Number:

Based on the foregoing, this research focuses on how the aspects of the strength of the proof of an underhand deed that have been legalized/waarmeking by a notary? How are legal considerations applied by judges in examining and deciding cases? Number 13 PDT/2020/PT.MTR?

${ }^{6}$ Cici Harfiah, Op. Cit., p. 97 


\section{Research Methods}

This research is a normative juridical law research. Normative legal research is legal research conducted by examining materials derived from various laws and regulations and other materials from various literatures that have correlation and relevance to the problems to be studied, as well as legal theories and opinions of scholars. In other words, this research examines library materials or secondary materials. This normative juridical research uses secondary data. The secondary data in question consists of primary legal materials, secondary legal materials, and tertiary legal materials.

\section{Result and Discussion}

The decision of the case Number 13 PDT/2020/PT.MTR as stated in the decision sheet of the Mataram High Court, the parties litigating the Plaintiff are PT. Lombok Mulia Jaya while the defendant is a citizen of China / China. This dispute arose because the parties felt that each of them was harmed or in default by not implementing it as stated in the contents of the joint venture agreement made under the hand that had been waarmeking at the Notary Office of Adrianto Anwar, SH, M.Kn, Jakarta Notary under Number: 352/waarmeking/2017 May 30, 2017.

Mediation efforts by the Praya District Court failed. The Judex factie trial process at the Praya District Court based on the available evidence was strengthened by the confessions of the parties, the Judge stated that "Declaring the Law that the Joint Venture Cooperation agreement Number: 352/WAARMEKING/2017 dated 30 May 2017 Notary Adrianto Anwar, SH, M.Kn and the contents of the cooperation agreement dated November 17, 2018 remain binding until the defendant of the Counterclaim/Plaintiff of the Convention has fulfilled his obligations" because the agreement has been agreed upon and is in accordance with the terms and validity of the agreement based on law, and must be carried out by the party who made it. This means that in this case the evidence of an underhand deed is perfect evidence because each party acknowledges the agreement they have made.

According to HS Salim, ${ }^{7}$ Agreements or commonly referred to as contracts have a very important role in social life and the business world. This is because in the contracts made by the parties, both between individuals and individuals, as well

${ }^{7}$ HS, Salim, (2017) Op Cit, p. 1 
as between individuals and legal entities as well as between legal entities and the state, there are mutual rights and obligations between them. This means that the parties mutually carry out their obligations and both have rights. The rights and obligations contained therein provide legal certainty between the parties. This certainty includes the certainty of the date the agreement is made and the entry into force of the agreement, its legal subject, its substance, which contains the will of the parties, the conditions, and witnesses. Agreements made by the parties are divided into two forms, namely verbal agreements and written agreements. An oral agreement is a sufficient agreement based on the verbal agreement of the parties, by simply saying "agree" or "disagree" about the object to be agreed between them. Written agreements are divided into two types, namely private deeds and authentic deeds.

In the above case, an underhand deed is a deed made by the parties without the involvement of a notary. Normatively or empirically, there have been many types of agreements made by the parties, both of which have been known in book I of the Civil Code, Book III of the Civil Code and those that are scattered in various laws and regulations outside the Civil Code.

Article 1313 of the Civil Code begins the provisions stipulated in the second Chapter of Book III of the Civil Code, under the title "Regarding engagements born of contracts or agreements", by stating that "an agreement is an act whereby one or more persons bind themselves to one one or more people". The formula given is to show us all, that an agreement is:
a. A Deed
b. Between at least two people (so can be more than two people)
c. This act gave birth to an agreement between the promised parties.

Written evidence in civil cases is the main evidence, because in civil traffic, people often intentionally provide evidence in making an agreement that can be used if a dispute arises. In general, it can be said that if a person by way of agreement enters into an agreement, because that person wants it, then what is the basis for binding himself is his will or intention. People's intentions cannot be known directly, therefore in social life, people can know what is desired by each other only from the requirements that are spoken either orally or in writing. In writing, the statement is what manifests the will of the person and because the intention of the person cannot be touched or seen, the attachment of a person to the statement is the embodiment of his intention or will. Based on the foregoing, the law recognizes the existence of binding conditions; either according to written regulations, or according to unwritten or customary regulations. 
In theory, an agreement arises on the basis of an agreement, occurs because there is an intention from the people concerned, but practically what is the handle is the statement of the will or intention. based on the statement of mutual intention, then an agreement occurs and from the agreement the rights and obligations for both parties or one of the parties come out. The rights of one party are in conflict with the obligations of the other party, so this gives the right to sue. In a reciprocal agreement, both parties have the right to claim and each has obligations. It is tied to the question of will or intention, it is very important to use it as a letter. Judges at a trial really need evidence to be able to provide a settlement (decision) based on the evidence submitted. In the process of proof, the truth will be determined according to law and can guarantee the protection of the rights of the litigants in a balanced manner. In the trial, if what is submitted is only a deed under the hand given the limited strength of proof, so that other evidence is still being sought to support it so that other evidence is obtained which is considered sufficient to reach the truth according to law. Based on the foregoing, the authentic deed and deed under the hand that are recognized, against anyone, are undeniable evidence that the parties concerned have put down the statement as written in the deeds.

Regarding legalization and waarmeking in article $1874 \mathrm{BW}$ it is stated that:

"As underhand writings are considered underhanded deeds, letters, registers, household affairs letters and other writings made without the intermediary of a public employee. By signing an underhand writing, a thumbprint is in question, affixed with a dated statement from a Notary or another official appointed by law from which it turns out that he knows the person who put the thumbprint, or that this person has been introduced to him, that the contents of the deed have been explained to that person, and after that the thumbprint is affixed in front of a public employee. The employee must open the writing. By law, further regulations regarding the said statement and bookkeeping may be made".

The authority to legalize and trade private documents is not only given to a Notary, but also before other officials, such as the head of the District Court, the mayor, and others as referred to in Article Ordinantie Staatblad Number 46 jo 43, the legalization and waarmeking referred to here is:

a. Legalization is the ratification of letters made under the hand in which all parties who make the letter come before a Notary, and the Notary reads and explains the contents of the letter, then the letter is dated and signed by the parties and finally legalized by the Notary.

b. Waarmeking is registration by affixing a stamp and then registering it in the registration book provided for it. 
Letters made under the hand that have been legalized or traded by a Notary are registered in a special book (article 15 paragraph (2) letters $a$ and $b$ of the UUJN). record the underhanded deeds, among others, determine that the books in the register contain:

a. Book number and date

b. The name of the person who puts the signature or fingerprint on the deed

c. Date and brief contents of the deed

The purpose and objective (streking) of the act of signing is a legal fact (rechtfeit), which is a statement of the will of the signatory (signator), that he by affixing his signature under an inscription requires that the writing be considered by law as his own writing. ${ }^{8}$ Sometimes in society there is a misunderstanding about the meaning of legalization or waarmeking. Their opinion is that by legalizing or diwaarming the letter under the hand, the letter has obtained the position as an authentic deed, as if the letter was made by or before a Notary, even though the public official in question only guarantees the date and signature of the parties concerned. Here it is clear that private deeds which are between the date of manufacture and the occurrence of different legal events need to be waarmeking by a Notary or an agreement that has been agreed upon by the parties, to be further recorded in a special book. So that in waarmeking the parties do not need to come before a Notary, just a deed under the hand that has been signed by the parties is brought to the Notary.

a. That the content is permitted by law

b. The person who signed is the person concerned

c. The date on the deed under the hand is the date the deed was signed

Waarmeking only has the meaning of confirming the date, meaning that on the date the deed under the hand was diwaarmeking, the deed already existed, the Notary did not read out the contents of the deed that was waarmeking. The underhanded deed which is waarmeking from the Notary assists the judge in terms of proof because with the recognition of the signature, the contents of the deed are considered as an agreement of the parties, because the deed under the hand of truth lies in the signature of the parties, then with the recognition of the signature, the deed becomes perfect evidence.

Part of the community is less aware of the importance of a document as evidence so that an agreement between the parties is enough to be carried out with mutual trust and made orally, especially in people who are still surrounded by strong customs. For important events, evidenced by testimonies from several

${ }^{8}$ Notodisoerjo, Soegondo (1982) Hukum Notariat di Indonesia, Jakarta, Rajawali , p.205 
witnesses, usually the witnesses for that event are neighbors, friends in the village or officials in the area where the agreement was made. In fact, in the testimony using several witnesses, there are weaknesses, if there is an event that must be proven true, in the event of a dispute between the parties which must be proven true, then the witnesses will prove the truth by giving their testimony.

On the other hand, the community has realized and understood the importance of making written form of an important event as evidence by recording it in a letter (document) and signed by interested persons witnessed by two or more witnesses. Based on this, the public realizes that written evidence is an important means of proof in legal traffic, both in the sense that the material is in the presence of written evidence, as well as in a formal sense concerning the strength of the evidence itself. The obligation to prove this is based on article 1865 of the Civil Code which states: "Everyone who argues that he has a right, or to confirm his own right or to refute a right of another, refers to an event,

Discussing the problem of evidence in article $284 \mathrm{RBg}$ (Rechtsreglement Buitengewesten) Jo article 1866 of the Civil Code states, what is called evidence, namely. ${ }^{9}$
a. Letter Proof
b. Witness Evidence
c. conjecture
d. Confession
e. Oath

Gustav Radbruch, in the concept of "Standard Priority Teachings"10argues that there are three basic ideas of law or three legal objectives, namely justice, expediency and legal certainty. Justice is the main thing of the three things but that does not mean the other two elements can be ignored immediately. A good law is a law that is able to synergize these three elements for the welfare and prosperity of the community. Justice in question is justice in a narrow sense, namely equal rights for all people before the court. Expediency or finality describes the content of the law because the content of the law is indeed in accordance with the objectives to be achieved by the law, while legal certainty is interpreted as a condition in which the law can function as a regulation that must be obeyed. Notaries not only make authentic deeds but also register and ratify

\footnotetext{
${ }^{9}$ Tresna, R, (1996) Komentar HIR, Jakarta, Pradnya Paramita , p.141

${ }^{10}$ Prayogo, Tony R (Application of the principle of legal certainty in the Supreme Court Regulation Number 1 of 2021 concerning the right to judicial review and in the Constitutional Court Regulation Number 06/PMK/2005 concerning Procedures Guidelines for the Judiciary of Laws, Directorate General of Legislation, Ministry of Law and Human Rights, Jakarta, 2016.

https://e-jurnal.peraturan.go.id/index.php/ili/article/download/151/pdf, accessed on 29 July 2021 at 23:34 WIB
} 
under-handed deeds such as Waarmeking, provide legal advice and legal explanations to the parties who make them and make deeds of establishment and amendments to limited liability companies at the Ministry of Law and Human Rights. The objectives of the legalization and waarmeking of the signing of the deed under the hand are. ${ }^{11}$

a. So that there is certainty of the truth that the signature is correct as the signature of the parties

b. Thus, the parties are basically no longer free to sign what is contained in the deed

Regarding the authority to legalize and trade Odonantie Staatblad 1916 number 46 in conjunction with number 43 states: Article 1 : in addition to a notary, also appointed to legalize and waarmeking the deed under the hand are the regent, the head of the district court and the mayor. Article 2 paragraph (2) of an underhand deed which is not legalized if it is to be used as evidence in court, can be waarmeking by a Notary by affixing the words "marked" and signed by the Notary and also mentioning the day, month, when he was waarmed. In Article 3 of the Staatblad 1916 Number 46, it is stated that an arrangement concerning the register must be made to record the deeds under the hand, among other things stipulating that the books in the register make, among other things.

a. Number and date of bookkeeping;

b. The name of the person who puts the signature or fingerprint on the deed

c. The date of the short contents on the deed

Scientifically the intent and purpose (streking) of the act of signing a legal fact (rechtfeit), namely: ${ }^{12}$ "a statement of the will of the signatory (signator) that by signing it under the hand of a writing he wishes that the writing is considered as his own writing by law"

In addition to making an authentic deed, in the procedure for making a deed, you must follow the rules or applicable laws. Deeds that are administrative in nature have been regulated in the rules made by the government and the Ministry of Law and Human Rights of the Republic of Indonesia. One of the powers of a Notary is to form an Authentic deed contained in Article 15 of the Law on Notary Positions which explains two things as follows:

\footnotetext{
${ }^{11}$ M.yahya Harahap, Op Cit p. 597

12 Thong Kie, Tan (2000) Studi Nitariat Praktek Notaris buku II, Jakarta, Ichtiar Baru Van Hoeve, p.288
} 
a. The notary has the authority to make an authentic deed according to the wishes of the interested parties as long as the contents of the deed made and the procedure for making it do not violate the rules or provisions of the law.

b. A Notary also has the authority to provide certainty on the date of documents or letters under the hand by registering in a special book owned by a Notary or known as a waarmeking book and keeping photocopies of documents under the hand that already have certain dates. ${ }^{13}$

Article 16 letter $\mathrm{E}$ of the UUJN explains the reasons that a Notary can use if he refuses the wishes of the parties to make a deed or one of the reasons that causes a Notary to be impartial. For example, if there is a close relationship or family relationship with the Notary, both his wife/husband, the point is that if any of the parties have a close relationship or family relationship with the Notary or his family, the Notary can refuse to make a deed. Another example is like one of the parties who wants to make an agreement or deed does not have the skills or ability to carry out a legal act or other things that are not permitted by applicable regulations.

The case of PT Lombok Mulia with the Chinese citizen Riu Jun, especially regarding the strength of proof of an underhanded letter that has been warranted, because if you look at the provisions in book IV of the Civil Code in articles 1874, 1974a, 1880 it is stated that the letter in question needs to be legalized from a notary. In relation to the authority of the Notary as a public official, the letter under the hand can be strengthened through legalization and waarmeking (register). The difference between Register (waarmeking) and Legalization is that "waarmeking" only has a certain date and no signature certainty, while the legalization of the signature is carried out in front of the legalizing person, while for waarmeking, at the time of waarmeking, the letter is already signed by the person concerned. ${ }^{14}$

The registration of this private letter or waarmeking has not been specifically and editorially regulated, but regarding legalization, it can be found in Act No. 2 of 2014 concerning amendments to Act No. 30 of 2004 concerning Notary Positions, in article 15 paragraph (2) letter a stating that the Notary in his position has the authority to ratify the signature and determine the certainty of

${ }^{13}$ Dwipraditya, AABI \& All (2020) "Tanggungjawab Notaris terhdap keabsahan tanda tangan para pihak pada perjanjian dibawah tangan yang diwaarmeking" Jurnal Kontruksi Hukum Vo 1, No. 2 October 2020, p. 233.

https://www.ejournal.warmadewa.ac.id/index.php/jukonhum/article/download/2599/1840/ accessed on Tuesday, July 13, 2021 at 05.25 WIB

${ }^{14}$ A. Pilto, (1986) Pembuktian dan Daluwarsa Menurut Kitab Undang-undang Hukum Perdata, Intermasa, Jakarta, p. 34 
the date of the letter under the hand by registering it in a special book. However, the application of underhand letters registered by a Notary has many problems, many misunderstand, underhand letters registered by a Notary do not have a clear legal basis, only regulated in the Notary Office Act. However, the legal force of the letter registered under the hand of the Notary is not explained.

The weakness of an underhand letter that is registered with a Notary is that the Notary does not know the contents of the underhanded letter and the letter is not intended for a particular crime. The notary is only authorized to register the letter without seeing or asking for clear information for the contents of the agreement letter. as in the verdictNumber 13 PDT/2020/PT.MTR that the Notary in this case is not required to examine the contents of the letter and the Notary is not a defendant because what the Notary did was not wrong. Because Notaries are only subject to the Law on Notary Positions. In the case of Article 15 paragraph (2) letter $b$, the Notary in his position is also authorized to record the letter under the hand by registering it in a special book. In the Act it is not explained that a Notary must check the contents, and call both parties to be responsible for the contents in the letter under the hand.

In the Civil Code it is not explained about the strength and position of the deed under the hand recorded by the Notary, but in the contents of the decision Number 13 PDT/2020/PT.MTR, that the deed under the hand that has been waarmeking by the Notary is used as evidence in the trial whose legal power is very weak, this is because there is a judge's consideration of other evidence.

Juridically waarmeking is actually only a legal action of a Notary or other public official who has the authority according to law, to record and register letters under the hands that have been made by the parties in a special book. Waarmeking does not state the truth of the date and signature and the truth of the contents of the said underhanded agreement as the legality or ratification of the authentic deed or legalization is carried out in accordance with the Civil Code, and has been explained as to its strength in terms of the evidentiary process, but for underhanded deeds registered by a Notary, according to the author for its strength and position in the evidentiary process cannot be equated with legalization or authentic deeds, therefore it is still necessary to find out again, so that it can become a new legal discovery,

Legal considerations applied by the judge in examining and deciding case Number 13 PDT/2020/PT.MTR In the case between PT. Lombok Mulia with RUI Jun Chinese citizen regarding the cancellation of the joint venture agreement made under the hand that has been waarmeking at the Notary Office of Adrianto Anwar, SH, M.Kn, Jakarta Notary, under Nomo: 352/Waarmeking/2017 dated 30 May 2017, the examining judge concluded that there is a violation committed by one of the parties so that the agreement needs to be changed in the editorial 
sentence so as not to change its meaning or the agreement has no legal force. These considerations are based on the evidence submitted by the parties in the trial.

The authority of a Notary in conducting waarmeking as stated by Philipus $M$ Hadjhon that the authority and authority and sources of authority is very diverse, some linking authority to power and distinguishing between attribution, delegation and mandate. All government actions are required to be based on the principle of legal authority. The authority is obtained from three sources, namely attribution, delegation and madat. The authority of attribution is usually outlined through the division of state power by the constitution, while the authority of delegation and mandate is the authority that comes from expropriation. In the event that the delegation regarding the delegation procedure originates from a government organ to another government organ with statutory regulations. ${ }^{15}$

According to subekti, proving is "convincing the judge of the truth of the arguments or arguments put forward in a dispute". ${ }^{16}$ What is meant by proof is "Juridical proof is nothing but historical evidence. This historical proof tries to establish what has happened concretely. In both juridical and scientific evidence, proving the truth means considering logically why certain events are considered true. ${ }^{17}$ In the trial, if what is submitted as evidence is only a deed under the hand given the limited strength of the proof, so that other evidence is still being sought to support it, so that evidence is obtained which is considered sufficient to reach the truth according to the law, then the deed under the hand can only be accepted as a start. written evidence (article 1871 of the Civil Code) but according to the article it is not explained what is meant by written evidence." 18 Article 1902 of the Civil Code states that if there is preliminary written evidence, namely that there must be a deed, the deed must be made by the person against

\footnotetext{
${ }^{15}$ Puasa Rilandi R \& All (2018) Kewenangan Pemerintah desa dalam peningkatan perekonomian didesa mahagiang kecamatan tagulandang kabupaten kepulauan sitaro, Jurnal Jurusan IImu $\begin{array}{llll}\text { Pemerintahan } & \text { Volume } & 1 & \text { No. }\end{array}$ https://ejournal.unsrat.ac.id/index.php/jurnaleksekutif/article/view/21120 accessed on July 31, 2021 at $21: 12$ WIB

${ }^{16}$ R. Subekti, (2001) Hukum Pembuktian, Pradnya Paramita, Jakarta, p. 1

17 Sudikno Metokusumo,(1988) Hukum acara perdata Indonesi, Edisi ketiga, Liberty, Yogyakarta, p. 109

18 Meitinah, Kekuatan Pembuktian Akta dibawah tangan yang telah diperoleh Legalisasi dari Notaris, Jurnal Hukum dan Pembangunan, Tahun-36 No. 4, 2006, p. 457-458 https://www.researchgate.net/publication/318650986 KEKUATAN PEMBUKTIAN AKTA DI BA WAH TANGAN YANG TELAH MEMPEROLEH LEGALISASI DARI NOTARIS/fulltext/59754a9aaca 2728d025458c7/KEKUATAN-PEMBUKTIAN-AKTA-DI-BAWAH-TANGAN-YANG-TELAHMEMPEROLEH-LEGALISASI-DARI-NOTARIS.pdf accessed on July 13, 2021 at 11.02 WIB
} 
whom the claim is made or from the person he represents, and the deed must allow the truth of the event in question. ${ }^{19}$

So a deed under the hand to be perfect and complete evidence from the beginning of the written evidence must still be equipped with other evidence, therefore it is said that the deed under the hand is written evidence (begin van schriftelijk bewijs). In the case above, it can be explained that several provisions of the legislation, which can be stated in Article 1865 of the Civil Code which states: Everyone who argues that he has a right, or in order to confirm his own right or to refute a right of another, designates an event that is obliged to To prove the existence of such rights or events, Article 1866 of the Civil Code determines that evidence consists of written/letter evidence, evidence with witnesses, suspicions, confessions and oaths.

The legal force of an underhand agreement deed registered by a Notary (waarmeking), the strength of proof only includes the fact that the certificate is given, if the signature is recognized by the signer or is considered to have been recognized in such a way according to law for an under-handed deed, the strength of the proof will depend very much on the truth of the parties' acknowledgment or denial of the contents of the deed and their respective signatures. If a deed under the hand is recognized by its contents and signature by each party, the strength of the proof is almost the same as that of an authentic deed, the difference lies in the strength of birth proof, which is not automatically owned by the deed under the hand.

Underhand deeds that have been registered / waarmeking do not have legal force to be used as evidence against third parties, but for the first and second parties they can be used as evidence as long as the parties acknowledge the signature and contents of the deed. in the event that the signature is denied, the judge must order that the veracity of the deed be examined. If the signature is recognized by the person concerned, then the deed under the hand has the power and becomes perfect evidence. The contents of the statement in the deed under the hand can no longer be denied, because the signature on the deed under the hand has been recognized by the person concerned. An underhand deed agreement that has been waarmeking is a perfect proof,

\section{Closing}

The strength of proof of an underhand deed registered by a Notary (waarmeking) according to article 1875 of the Civil Code, then a private deed that is recognized by the person against whom the deed is used or which is

${ }^{19}$ R. Soegondo Notodioerjo, (1993) Hukum Notariat di Indonesia suatu penjelasan, print. II, Raja Grafindo Persada, Jakarta, p. 44 
considered recognized according to the law for the signer, as well as the people who have the right of that person is perfect evidence such as an authentic deed. The contents of the information in the deed under the hand are true to who made it and for the benefit of the person for whom the statement was made, the deed that has been registered with the Notary for the judge has obtained certainty regarding the date, identity and fulfillment of the 1320 Civil Code of the party who entered into the agreement as well as the signature affixed under the letter is true to origin and affixed by the person whose name is listed in the deed without any pressure or intervention. The value of the strength of proof of an underhand deed must fulfill formal and material requirements, namely made at least 2 (two) parties without the intervention of an authorized official and the contents of the signature are recognized by each party, then according to the provisions of Article 1875 of the Civil Code, the value of the strength of the proof is the same as the deed. authentic, thus the power of proof attached to it is perfect and binding (volledig en bindendebewijskracht). The legal aspect in proving an underhand deed that has been waarmeking in terms of proof in court is that it does not have perfect proof power when each party denies the contents of the underhand deed. different from an authentic deed which has definite evidentiary power, then the deed under the hands of the power of proof is in the hands of the judge to consider it (Article 1881 paragraph (2) of the Civil Code. Cooperation agreements through authentic deeds have perfect evidentiary certainty in the eyes of the law

\section{References}

\section{Al Qur'an and Hadits}

[1] Al-Quran dan Terjemahannya, Riyadh: Darussalam Global Leader in Islamic Books, 2006

[2] Kurnia lyus. Et al., Al-Quran Cordoba The Amazing: 33 Tuntutan Al- Quran untuk hidup anda, Bandung, Cordoba , 2012

Journals:

[1] Deen, Thaufiq., Ong Argo Victoria \& Sumain. (2018). Public Notary Services In Malaysia. JURNAL AKTA: Vol. 5, No. 4, 1017-1026. Retrieved from http://jurnal.unissula.ac.id/index.php/akta/article/view/4135

[2] Dwipraditya, AABI \& All "Tanggungjawab Notaris terhdap keabsahan tanda tangan para pihak pada perjanjian dibawah tangan yang diwaarmeking" Jurnal Kontruksi Hukum Vo 1, No. 2 Oktober 2020 https://www.ejournal.warmadewa.ac.id/index.php/jukonhum/article/do wnload/2599/1840/ accessed on Tuesday 13 July 2021 at 05.25 WIB 
[3] Meitinah ( 2006) , Kekuatan Pembuktian Akta Di Bawah Tangan Yang Telah memperoleh Legalisasi dari Notaris, Jurnal Hukum dan Pembangunan, Tahun Ke-36 No.4

[4] Prayogo, Tony R ( Penerapan asas kepastian hukum dalam peraturan mahkamah agung Nomor 1 tahun 2021 tentang hak uji materiil dan dalam peraturan mahkamah konstitusi Nomor 06/PMK/2005 tentang pednoman beracara dalam pengujuian undang-undang, Direktorat Jenderal Peraturan Perundang-undangan kementerian hukum dan HAM, Jakarta, $2016 . \quad$ https://ejurnal.peraturan.go.id/index.php/ili/article/download/151/pdf, Accessed on, 29 July 2021 at 23:34 WIB

[5] Puasa Rilandi R \& All (2018) Kewenangan Pemerintah desa dalam peningkatan perekonomian didesa mahagiang kecamatan tagulandang kabupaten kepulauan sitaro, Jurnal Jurusan IImu Pemerintahan Volume 1 No. https://ejournal.unsrat.ac.id/index.php/jurnaleksekutif/article/view/2112 $\underline{0}$ Accessed on 31 July 2021 at 21:12 WIB

[6] Rahmadhani, Febri "Kekuatan Pembuktian Akta di Bawah Tangan Waarmerking Dalam Perspektif Peraturan Perundang-undangan di Indonesia" jurnal Recital Review Vol.2 No. 2 Tahun 2020

Books:

[1] Asnawi \& M Natsir, Hermeneutika Putusan Pengadilan, Yogyakarta: UUI Press, 2019

[2] Adji Habib \& Sjaifurrahman, Aspek Pertanggungjawaban Notaris dalam Pembuatan Akta, CV Mandar Maju, 2011

[3] Adjie Habib, Kebatalan dan Pembatalan Akta Notaris, Bandung: Refika Aditama, 2011

[4] Adam Muhammad, IImu Pengetahuan Notariat, Bandung: Sinar Baru, 1985

[5] A. Pilto, Pembuktian dan Daluwarsa Menurut Kitab Undang-undang Hukum Perdata, Jakarta: Intermasa, 1986

[6] Andasasmita, Komar, Akta II Notaris dan Contoh-contoh Akta, Jakarta: Ikatan Notaris Indonesia, 1997

[7] Handoko Widhi, Dominasi Negara terhadap Profesi Notaris antara ide dan realitas, Bogor, PT Roda Publika Kreasi, 2019

[8] Harahap, Yahya. Hukum Acara Perdata Tentang Gugatan, Persidangan, Penyitaan, Pembuktian, dan Putusan Pengadilan, Jakarta: Sinar Grafika, 2005

[9] HS, Salim, Peraturan Jabatan Notaris, Jakarta Timur: Sinar Grafika , 2018 [10] ----------, Teknik Pembuatan Akta Perjanjian (TPA Dua), Depok: PT Raja Grafido Persada, 2017 
[11] Hadjon, M, Philipus, Hukum Administrasi Negara, Yogyakarta: Gadjah Mada University Press, 2001

[12] Harahap, Yahya, Hukum Acara Perdata Gugatan, Persidangan, Penyitaan, Pembuktian, dan putusan Pengadilan Edisi Kedua, Jakarta: Sinar Grafika, 2017

[13] HS, Salim, Teknik Pembuatan Akta Perjanjian (TPA DUA), Jakarta: PT Raja Grafindo Persada, 2017

[14] H.S Salim, Perencangan Kontrak dan Memorandum of Understanding ( $\mathrm{MOU}$ ), Jakarta: Sinar Grafika, 2008

[15] Mansyur, M. Ali , Hukum Perdata Perikatan, Semarang, Unissula Pres, 2008

[16] Moleong, Lexy, Metodologi Penelitian Kualitatif Edisi revisi, print. ke 27, Bandung: PT Remaja Rosdakarya, 2010

[17] Mertokusumo, Sudikno, Hukum Acara Perdata Indonesia, Yogyakarta: Liberty, 2006

[18] M. Situmorang, Victor, Grosse Akta Dalam Pembuktian Dan Eksekusi, Jakarta: Rineka Cipta, 1993

[19] Muljadi, Kartini \& Widjaja, Gunawan, Perikatan yang lahir dari Perjanjian, Jakarta: PT Grafindo Persada, 2014

[20] Notodisoerjo, Soegondo, Hukum Notariat di Indonesia, Jakarta: Rajawali, 1982

[21] Ngadino, Rekontruksi Ideal Pengawas Notaris Berbasis Hukum Progressif, Semarang: UPT Penerbitan Universitas PGRI Semarang, 2020

[22] Ngadino \& Ayu Saputri, Rahardian, Teknik Pembuatan Akta di Indonesia, Semarang: UPT Universitas PGRI Semarang Pres,2020

[23] ---------,Tugas dan tanggung jawab Notaris di Indonesiahuk, Semarang, Semarang: UPT Penerbitan Universitas PGRI, 2019

[24] Naja Daeng, Teknik Pembuatan Akta, Yogyakarta : Pustaka Yustisia, 2012

[25] Peter Mahmud Marzuki , Pengantar Ilmu Hukum, Jakarta: Kencana Pranada Media Grup, 2008

[26] Purnamasari, Devita Irma \& Suswinarno, Panduan Lengkap hukum praktis populer kiat-kiat cerdas, mudah dan bijak memahami masalah Akad Syariah, Bandung: PT Mizan Pustaka, 2017

[27] Prajudi Atmosudirdjo, Hukum Administrasi Negara, Jakarta: Ghalia Indonesia, 1995 )

[28] Roni Hanitijo Soemitro, Metodologi Penelitian Hukum, Jakarta: Ghalia Indonesia, 1988

[29] R. Soegondo Notodioerjo, Hukum Notariat di Indonesia suatu penjelasan, print. II , Jakarta: Raja Grafindo Persada, 1993

[30] R. Subekti, Hukum Pembuktian, Jakarta: Pradnya Paramita, 2001

[31] Sudikno Metokusumo, Hukum acara perdata Indonesi, Edisi ketiga, Yogyakarta: Liberty,1988 
[32] Sudikno Mertokusumo, Mengenal Hukum Suatu Pengantar, Yogyakarta: Liberty, 1999

[33] Suparmoko, Metode Penelitian Praktis. Yogyakarta, BPFE, 1991

[34] Seri Perundang-undangan, (2014) Kitab Lengkap KUH Per KUHAP Per KUHP KUHAP KUHD, Jakarta Selatan Pustaka Yustisia

[35] Sidarta, Arif (2007) Meuwissen, Tentang Pengembanan Hukum, Ilmu Hukum, Teori Hukum dan Filsafat Hukum, Bandung: PT Refika

[36] Satyagraha, Otong, Aspek Hukum Kekutan Pembuktian Akta Otentik di Pengadilan, Tesis Universitas Islam Indonesia, 2016

[37] Subekti, Hukum Pembuktian, Jakarta: PT Paramitha, 2005

[38] Sjaifurrachman \&Adjie Habis, Aspek Pertanggungjawaban Notaris dalam pembukatan akta, Bandung: CV Mandar Maju, 2011

[39] Thong Kie, Tan, Studi Notariat, Beberapa Mata Pelajaran dan Serba-serbi praktek Notaris, Jakarta: CV Ichtiar Baru Van Hoeve, 2000

[40] Tresna, R, Komentar HIR, Jakarta: Pradnya Paramita, 1996

[41] Thong Kie, Tan, Studi Nitariat Praktek Notaris buku II, Jakarta: Ichtiar Baru Van Hoeve, 2000

[42] R. Subekti, Hukum Pembuktian, Jakarta, Pradnya Paramita, 2001

Regulations:

[1] Act No. 2 of 2014 concerning amendments to Act No. 30 of 2004 concerning the Position of Notary

[2] Civil Procedure Code

[3] Code of Civil law

[4] Court Decision Number 13/PDT/2020/PT.MTR

Internet:

[1] Kamus Besar Bahasa Indonesia https://kbbi.kemdikbud.go.id/, Accessed on 4 March 2021 at 04.03 WIB

[2] https://ngobrolinhukum.wordpress.com/2013/02/05/memahamikepastian-dalam-hukum/accessed on 5 April 2021 at 04.53 WIB 